1352-2310(95) 00315-O

\title{
A MODEL OF AMMONIA VOLATILIZATION FROM A GRAZING LIVESTOCK FARM
}

\author{
N. J. HUTCHINGS \\ Macaulay Land Use Research Institute, Craigiebuckler, Aberdeen AB9 2QJ, U.K. \\ S. G. SOMMER \\ Danish Institute of Plant and Soil Science, Department of Soil Science, Foulum Research Centre, \\ 8830 Tjele, Denmark \\ and \\ S. C. JARVIS \\ Institute of Grass and Environmental Research, North Wyke, Okehampton, Devon EX20 2SB, U.K.
}

\author{
(First received 18 March 1995 and in final form 1 August 1995)
}

\begin{abstract}
A dynamic model was developed to predict the ammonia volatilization from grazing livestock farms and to allow potential control measures to be evaluated. The relationships within the model were based on the underlying physical and chemical processes but empirically based factors were used to reduce the demand for input data and where the understanding of the underlying processes was inadequate. On a daily basis, the model simulates the partitioning of dietary nitrogen into dung and urine and its subsequent fate within the pasture or the slurry handling system. The fate of dry matter and water added in dung, urine and from other sources is also predicted. The model illustrates the indirect interactions between ammonia sources, highlights the influence of slurry management on ammonia losses, stresses the need for integrated, whole farm measurements and demonstrates that assessments of the impact of control measures may be misleading unless considered at the scale of the whole farm.
\end{abstract}

Key word index: Model, ammonia volatilization, animal housing, slurry, manure, urine.

\section{INTRODUCTION}

Animal production systems are the major source of atmospheric $\mathrm{NH}_{3}$ in Europe (Buijsman et al., 1987). Deposition of this $\mathrm{NH}_{3}$ may contribute to undesired changes in oligotrophic ecosystems (Schulze et al., 1989 ) and volatilization reduces the nutrient value of animal manures.

Previous studies have assessed the magnitude of $\mathrm{NH}_{3}$ losses at a large scale and the specific contribution of agriculture (e.g. Buijsman et al., 1987; ApSimon et al., 1987; Jarvis and Pain, 1990). Estimates of agriculture's contribution differ widely (Lee and Dollard, 1994), indicating the need for improved information. Others have considered the losses associated with specific on-farm sources such as animal housing (Janssen and Krause, 1990) or waste storage (Olesen and Sommer, 1994) or farming practices such as slurry spreading or grazing (e.g. van der Molen et al., 1990; Pain et al., 1989; Jarvis et al., 1991; Sommer et al., 1991). On-farm $\mathrm{NH}_{3}$ sources are often linked, as, for example, where excreta are voided in animal housing, transferred to a slurry store and then event- ually applied to the land. Assessing the true impact of control measures designed to limit $\mathrm{NH}_{3}$ loss requires a whole farm approach. Earlier models capable of simulating $\mathrm{NH}_{3}$ volatilization at the farm scale have been static (Hansen et al., 1990) and often embedded within models of the whole $\mathrm{N}$ economy (Scholefield $e t$ al., 1991; van de Ven, 1992). There is a need for a dynamic model which focuses closely on $\mathrm{NH}_{3}$ volatilization at the farm level if detailed estimates of the $\mathrm{NH}_{3}$ losses from livestock farms are to be obtained and the true effectiveness of control measures assessed. The first version of such a model is presented here.

\section{MODEL STRUCTURE}

The model simulates $\mathrm{NH}_{3}$ sources on grazing livestock farms or the part of mixed enterprise farms that is used for grazing livestock. The model tracks the $\mathbf{N}$ input as animal feed until it is lost by volatilization or the area of land on to which it was deposited/applied ceases to be an active $\mathrm{NH}_{3}$ source. The routes of $\mathrm{N}$ flow within the model are shown in Fig. 1. 


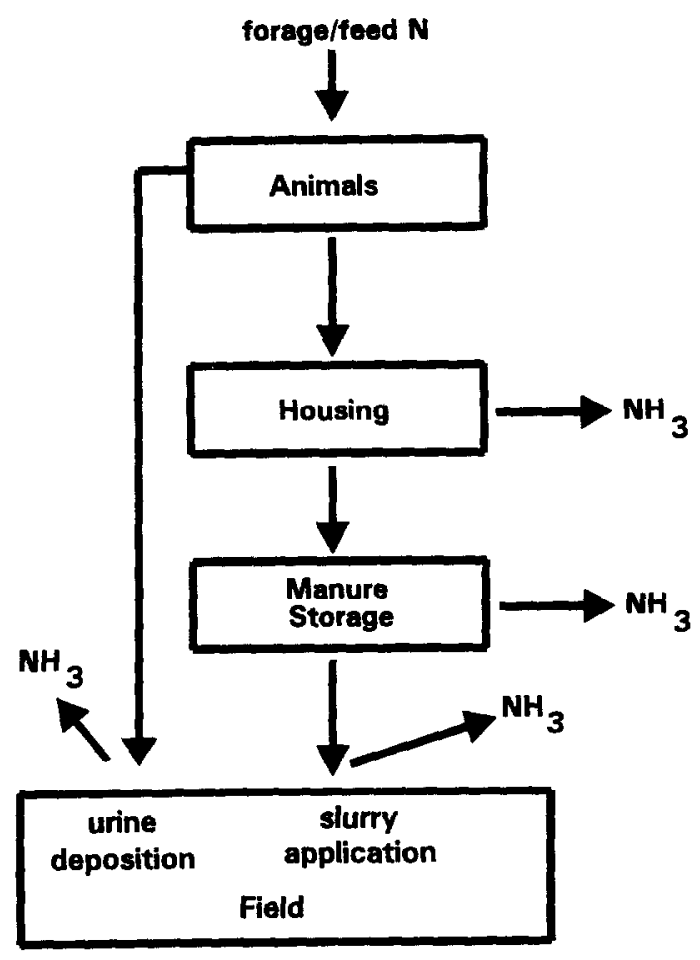

Fig. 1. The major routes for nitrogen flow in the $\mathrm{NH}_{3}$ volatilization model.

Three general assumptions are made: (a) the livestock are managed and behave as a single flock or herd, (b) volatilization of ammonia is nowhere limited by urease activity and (c) where two sources occupy the same land area in sequence, the second source does not interact with the first.

The model operates with a daily time step or less as losses are often nonlinearly related to environmental parameters, so estimating losses using a weekly or monthly figure could lead to serious error in the estimates of $\mathrm{NH}_{3}$ loss.

\section{A generalized $\mathrm{NH}_{3}$ source}

The sources of $\mathrm{NH}_{3}$ on a farm share a common feature. The $\mathrm{NH}_{3}$ is volatilized from the surface of an aqueous solution of $\mathrm{NH}_{4}^{+}$and is then transported through a pathway with a finite resistance to the free atmosphere. Ignoring the concentration of $\mathrm{NH}_{3}$ in the free atmosphere, the volatilization of $\mathrm{NH}_{3}$ from an aqueous solution $x\left(A_{x} ; \mathrm{kg} \mathrm{d}^{-1}\right)$ can be described as

$$
A_{x}=\frac{a_{x} \operatorname{TAN}_{x} Q_{x} \gamma}{r_{x} V_{x}}
$$

where $a_{x}$ is the surface area of solution exposed to the air $\left(\mathrm{m}^{2}\right), \mathrm{TAN}_{x}$ is the total ammoniacal N (TAN) in solution $x\left(\mathrm{~kg} \mathrm{~m}^{-2}\right), Q_{x}$ is a dimensionless equilibrium coefficient determining the $\mathrm{NH}_{3}$ gas in the air for a given concentration of TAN in solution $x, r_{x}$ is the resistance to $\mathbf{N H}_{3}$ transport between the surface of solution $x$ and the free atmosphere $\left(\mathrm{d} \mathrm{m}^{-1}\right), V_{x}$ is the mass of the solution $\left(\mathrm{kg} \mathrm{m}^{-2}\right)$ and $\gamma$ is the density of the solution, assumed here to have the same value as water $\left(1000 \mathrm{~kg} \mathrm{~m}^{-3}\right)$. This relationship is used as the basis for submodels of all the major sources on the farm.

Following Sherlock and Goh (1985a), $Q_{x}$ can be described as

$$
Q_{x}=K_{\mathrm{b}, x} K_{\mathrm{NH}_{4}, x}
$$

where $K_{\mathrm{h}, x}$ is the Henry's law coefficient and $K_{\mathrm{NH}_{4}, x}$ is the dissociation coefficient of ammonium:

$$
\begin{aligned}
K_{\mathrm{h}, x} & =10^{\left(-1.69+1477.7 / \theta_{x}\right)}, \\
K_{\mathrm{NH}_{4}, x} & =1+10^{\left(0.09018+\left(2729.92 /\left(\theta_{x}+273\right)\right)-\mathrm{pH}_{x}\right)}
\end{aligned}
$$

where $\theta_{x}$ and $\mathrm{pH}_{x}$ are, respectively, the temperature $\left({ }^{\circ} \mathrm{C}\right)$ and $\mathrm{pH}$ of the liquid. The resistance to transport $\left(r_{x}\right)$ will vary between sources, as described in detail below.

The rate of $\mathrm{NH}_{3}$ loss predicted by equation (1) is very sensitive to the $\mathrm{pH}$ over the range commonly encountered in urine and slurry. The $\mathrm{pH}$ of slurry and urine changes with time of exposure to air as $\mathrm{NH}_{3}$, $\mathrm{CO}_{2}$ and $\mathrm{H}_{2} \mathrm{O}$ are lost. Also, the relationship between volatilization and initial $\mathrm{pH}$ varies between slurries due to variations in the buffering capacities of the liquids (Husted et al., 1991). At present the changes with time and variation between slurries cannot be easily predicted. The approach adopted here is to simulate $A_{x}$ as a function of the initial value of $\mathrm{pH}_{x}$ using equation (1). Although the rate of loss is allowed to vary between the types of source, it is accepted that differences in buffering capacity will lead to error in simulating volatilization within a type.

An index of symbols is shown in Appendix A.

\section{ANIMAL SUBMODEL}

The use of equation (1) requires the quantity and form of $\mathrm{N}$ and the volume of urine/slurry to be known for each source. The faecal dry matter production must also be calculated as the solids content of slurry influences the $\mathrm{NH}_{3}$ lost after land application.

\section{Faeces}

The daily faecal dry matter output on the farm $\left(D_{f, t} ; \mathrm{kg} \mathrm{DM} \mathrm{d}^{-1}\right)$ is

$$
D_{\mathrm{f}, t}=S_{t} F_{t}\left(1-\alpha_{t}\right)
$$

where $\alpha_{t}$ is the apparent digestibility of the feed $\left(\mathrm{kg} \mathrm{DM}(\mathrm{kg} \mathrm{DM})^{-1}\right), S_{t}$ is the number of animals on the farm and $F_{t}$ is the quantity of feed eaten per animal (kg DM animal ${ }^{-1}$ ).

Faecal $\mathrm{N}$ is mainly of microbial origin (SCA, 1990) so the concentration of $\mathrm{N}$ in faeces varies little in response to variations in that of the feed. We assume a constant $\mathrm{N}$ concentration in faeces $\left(c_{\mathrm{f}} ; \mathrm{kgN}(\mathrm{kg} \mathrm{DM})^{-1}\right)$. The faecal $\mathrm{N}$ production 
$\left(N_{\mathrm{f}, t} ; \mathrm{kg} \mathrm{N} \mathrm{d}^{-1}\right)$ can be calculated as

$$
N_{\mathrm{f}, t}=D_{\mathrm{f}, t} c_{\mathrm{f}} .
$$

The water contained within the faeces $\left(V_{\mathrm{f}, t} ; \mathrm{kg} \mathrm{d}^{-1}\right)$ is

$$
V_{\mathrm{f}, t}=D_{\mathrm{f}, t} \beta
$$

where the faecal moisture content $\beta$ ( $\mathrm{kg}(\mathrm{kg}$ dry weight $)^{-1}$ ) is assumed to be a constant.

\section{Urine}

The urinary $\mathrm{N}$ production $\left(N_{\mathrm{u}, t} ; \mathrm{kg} \mathrm{N} \mathrm{d}^{-1}\right)$ is calculated by subtracting the $\mathrm{N}$ partitioned to milk, new animal tissuc and facces from the total intake

$$
N_{\mathrm{u}, t}=S_{\mathrm{t}}\left(F_{t} c_{\mathrm{h}, t}-\left(M_{\mathrm{t}} c_{\mathrm{m}}+K_{t} c_{\mathrm{w}}\right)\right)-N_{\mathrm{f}, \mathrm{t}}
$$

where $c_{\mathrm{h}, t}$ is the $\mathrm{N}$ concentration in the feed supply $\left(\mathrm{kg} \mathrm{N}(\mathrm{kg} \mathrm{DM})^{-1}\right), M_{t}$ is the milk yield (kg animal $\left.{ }^{1} \mathrm{~d}^{-1}\right), c_{\mathrm{m}}$ is the $\mathrm{N}$ concentration in milk $\left(\mathrm{kg} \mathrm{kg}^{-1}\right), K_{t}$ is the empty body weight gain $\left(\mathrm{kg} \mathrm{d}^{-1}\right)$ and $c_{w}$ is the $\mathbf{N}$ concentration in new tissue $\left(\mathrm{kg} \mathrm{Nkg}^{-1}\right)$.

The mass of urine produced $\left(V_{\mathrm{u}, t} ; \mathrm{kgd}^{-1}\right)$ is

$$
V_{\mathrm{u}, t}=S_{\mathrm{t}} u_{\mathrm{r}} u_{\mathrm{f}}
$$

where $u_{\mathrm{r}}$ is the urination rate $\left(\mathrm{kg}\right.$ urination $\left.{ }^{-1}\right)$ and $u_{\mathrm{f}}$ is the frequency (urinations animal ${ }^{-1} \mathrm{~d}^{-1}$ ). Both $u_{r}$ and $u_{\mathrm{f}}$ are assumed to be constants.

\section{AMMONIA LOSSES FROM ANIMAL HOUSES}

It has been shown that similar amounts of $\mathrm{NH}_{3}$ are lost per unit area from the floor and the surface of slurry stored beneath the floor (Voorburg and Kroodsma, 1992; Oosthoek et al., 1990). It is assumed here that losses occur from an area $\left(a_{1} ; \mathrm{m}^{2}\right)$ equal to the sum of the area of flooring occupied by the animals and the surface area of any slurry storage. Scraping the floor is assumed to have no effect on losses as a thin layer of manure is assumed to be left on the floor after scraping (Oosthoek et al., 1991). It is assumed that the $\mathrm{NH}_{3}$ emitting surfaces are formed only by freshly voided urine so $\mathrm{TAN}_{1, t}=N_{\mathrm{u}, t}$ and $V_{1, t}=V_{u, t}$. The effect of diluting urine with any water used for washing animals or flushing is ignored, although this water $\left(V_{\mathrm{w}, t} ; \mathrm{kg} \mathrm{d}^{-1}\right)$ is added to the slurry before it is passed to the slurry store.

Studies have shown that $\mathrm{NH}_{3}$ loss from animal houses is related to the indoor temperature (Muck and Richards, 1983; Burton and Beauchamp, 1986). Although this would be expected from equation (3), these losses are also due to increased ventilation, as the farmers try to limit the rise in indoor temperature (Oosthoek et al., 1990). There appears no simple way to separate these direct and indirect effects of temperature. The equilibrium coefficient $\left(Q_{1, t}\right)$ is calculated at a temperature of $20^{\circ} \mathrm{C}$; temperature effects are considered together with the resistance to $\mathrm{NH}_{3}$ transport (below). The $\mathrm{pH}$ is assumed to be that of urine (a model input) unless floor washings are artificially acidified, when the target $\mathrm{pH}$ is used.

The air flow pattern transporting the $\mathrm{NH}_{3}$ outside the housing is a complex function of both house design and ventilation strategy (Janssen and Krause, 1990). For simplicity, the resistance to transport $\left(r_{1, t}\right.$; $\mathrm{d} \mathrm{m}^{-1}$ ) is simulated using a relationship found by Mannebeck and Oldenburg (1991) which relates loss to the temperature of ventilation air, which we equate to the mean daily air temperature outside $\left(\theta_{t} ;{ }^{\circ} \mathrm{C}\right)$. The losses reported by Mannebeck and Oldenburg (1991) are here normalized by the loss at $20^{\circ} \mathrm{C}$ and multiplied by a housing-specific constant $\left(X_{1}\right)$ to obtain $r_{1, t}$ for both naturally and artificially ventilated housing:

$$
r_{1, t}=X_{1}\left(1-0.027\left(20-\theta_{t}\right)\right) .
$$

The housing-specific constant is used to adjust losses to match observed values. This relationship combines the effect of outside temperature on inside temperature, of ventilation rate and the effect of both inside temperature and ventilation rate on $\mathrm{NH}_{3}$ loss. The loss from animal housing $\left(A_{1, t} ; \mathrm{kg} \mathrm{Nd}^{-1}\right)$ is then

$$
A_{1, t}=\frac{H_{t} a_{1} \mathrm{TAN}_{1, t} Q_{1, t} \gamma}{r_{1, t} V_{1, t}}
$$

where $H_{t}$ is the proportion of the day during which the animals are housed. This submodel assumes that there is no interaction between faeces and urine (no buffering) and that losses are confined to the proportion of the day during which the animals are housed.

\section{AMMONIA LOSS FROM STORED SLURRY}

The surface area of the source $\left(a_{2} ; \mathrm{m}^{2}\right)$ is assumed to be that of the slurry store. The TAN is evaluated as the amount of ammoniacal $\mathrm{N}$ in the store (TAN $_{2, t} ; \mathrm{kg}$ ) and the volume by the volume of slurry present $\left(V_{2, i} ; \mathrm{kg}\right)$. Mineralization of slurry organic $\mathrm{N}$ is ignored. The use of bulk parameters will not accurately reflect conditions at the slurry surface but pH changes and stratification within the slurry are too poorly understood to predict with accuracy (Olesen and Sommer, 1994). A compromise is made by introducing a store-specific resistance to adjust the predicted loss to match empirical data (see below).

The equilibrium coefficient $\left(Q_{2, t}\right)$ is calculated equating the surface temperature to air temperature whilst the pH is assumed to be the mean for the whole store. Stratification will also introduce inaccuracies in $Q_{2, t}$ and these are also partially overcome by the store-specific resistance.

The wind speed affects the resistance to transport of $\mathrm{NH}_{3}\left(r_{2, t} ; \mathrm{d} \mathrm{m}^{-1}\right)$ through its effect on the aerodynamic resistance to transport from the slurry surface to the free atmosphere. Following Olesen and Sommer (1994), $r_{2, t}$ is made the sum of a boundary layer resistance $\left(r_{\mathrm{b}, t} ; \mathrm{d} \mathrm{m}^{-1}\right)$, an aerodynamic resistance $\left(r_{\mathrm{a}, i} ; \mathrm{d} \mathrm{m}^{-1}\right)$, a cover resistance $\left(r_{\mathrm{c}, i} ; \mathrm{d} \mathrm{m}^{-1}\right.$; the 
Table 1. Surface resistance for a range of coverings for slurry stores

\begin{tabular}{lc}
\hline Cover type & $\begin{array}{c}\text { Cover resistance } \\
\left(\mathrm{d} \mathrm{m}^{-1} \times 10^{-3}\right)\end{array}$ \\
\hline None & 0 \\
Straw & 0.59 \\
Oil & 2.11 \\
Peat & 2.67 \\
PVC sheet & 2.11 \\
Expanded clay & 4.42 \\
Lid & 6.71 \\
Crust & 2.13 \\
\hline
\end{tabular}

Calculated from data in Sommer et al. (1993).

resistance of the $i$ th slurry surface covering) and a store-specific resistance $\left(r_{\mathrm{T}} ; \mathrm{d} \mathrm{m}^{-1}\right)$. The values of $r_{\mathrm{b}, t}$ and $r_{\mathrm{a}, t}$ are determined in the manner described by Olesen and Sommer (1994) and then converted to daily values. The assumptions of adequate fetch and neutral stability that underlie this approach are unlikely to be met in full within a slurry store. This inadequacy is overcome by the use of the empirically determined store-specific resistance. The value of $r_{\mathrm{c}, i}$ for a variety of materials used for covering the slurry surface has been determined empirically (Table 1).

The rate of loss of $\mathrm{NH}_{3}$ from stored slurry $\left(A_{2, t}\right.$; $\mathrm{kg} \mathrm{Nd}^{-1}$ ) is

$$
A_{2, t}=\frac{a_{2} \operatorname{TAN}_{2, t} Q_{2, t} \gamma}{r_{2, t} V_{2, t}} .
$$

If the store dries out ( $V_{2, t}$ falls to zero), all the remaining TAN is assumed to volatilize but the dry matter remains.

\section{Loading frequency and position}

Ammonia loss rates are increased if fresh slurry is loaded on to the slurry surface as this increases the concentrations of $\mathrm{NH}_{4}^{+}$in the surface layer and disrupts any crust. Loss rates then fall over the subsequent $24-48 \mathrm{~h}$ as $\mathrm{NH}_{4}^{+}$in the surface layer is depleted and a crust re-forms. This effect is incorporated within the model by reducing the cover resistance to zero for the day on which slurry is added to the surface of the store.

\section{AMMONIA VOLATILIZATION DURING APPLICATION OF SLURRY}

Micrometeorological measurements have shown that losses during application using conventional spreaders, trail hose application and a cable-driven irrigator were less than $1 \%$ of the TAN applied (Pain et al., 1989; Phillips et al., 1991). Using broad spreading equipment, Sommer (1989) found volatilization during application to be less than $4 \%$ of the TAN applied. However, Boxberger and Gronauer
(1990) found losses of up to nearly $10 \%$ of applied TAN when using an irrigation device, although the greater losses in this latter study may have been due to the measurement technique used. We assume a proportion, $\Omega$, of the applied TAN is lost during application.

In the presence of a crop and when application is by broad spreader, a proportion of the slurry will be intercepted by the plant canopy. It is assumed that an amount $\eta\left(\mathrm{kg} \mathrm{m}^{-2}\right)$ of the slurry applied by broad spreading methods to planted land is intercepted by the crop. We assume there will be no direct foliar absorption and that all the TAN in intercepted slurry will be lost by volatilization.

Ammonia volatilized during spreading $\left(A_{3, t}\right.$; $\left.\mathrm{kg} \mathrm{Nd}^{-1}\right)$ is:

for spreading to land with a crop

$$
A_{3, t}=\left(\Omega R_{2, t}+a_{3 . b} \eta\right) \frac{\mathrm{TAN}_{2, t}}{V_{2, t}}
$$

for spreading to bare soil

$$
A_{3, t}=\Omega R_{2, t} \frac{\mathrm{TAN}_{2, t}}{V_{2, t}}
$$

where $R_{2, t}$ is the mass of slurry applied $(\mathrm{kg})$ and $a_{3, t}$ is the area covered by the slurry $\left(\mathrm{m}^{2}\right)$.

\section{AMMONIA LOSS FROM APPLIED SLURRY}

Unlike the sources in animal housing and manure storage, the source within an area to which slurry has been applied is not replenished. As a result, the rate of loss from surface-applied slurry is commonly highest shortly after application, declining rapidly thereafter (e.g. Pain et al., 1989; Sommer et al., 1991; Sommer and Ersbøll, 1994). The slurry $\mathrm{NH}_{4}^{+}$at risk of loss decreases with time through volatilization and through infiltration into the soil. The $\mathrm{NH}_{4}^{+}$that enters the soil becomes bound with the soil's cation exchange complex and is largely protected from volatilization. Here we identify the mass of slurry from which volatilization can take place $\left(V_{4, t}, \mathrm{~kg}\right)$ to be on or very near the soil surface. This mass is reduced by infiltration and evaporation and increased by rainfall. The TAN in this mass is decreased by volatilization and infiltration. Any upward movement of $\mathrm{NH}_{4}^{\prime}$ in the soil is ignored. The effect of rainfall on $\mathrm{NH}_{3}$ volatilization has been included as empirical data suggest that this is important (Beauchamp et al., 1982). The volatilization from slurry applications is described in Appendix B.

\section{Effect of application and cultivation methods}

Ammonia losses from slurry vary depending on the choice of application or cultivation technique. The mechanisms by which the different techniques affect loss vary. For example, rotovating the soil surface 
Table 2. Adjustments made to properties of slurry applications to reflect effects of different cultivations

\begin{tabular}{lll}
\hline Trcatment & \multicolumn{1}{c}{ Adjustment } & \multicolumn{1}{c}{ Sources $^{2}$} \\
\hline Pre-application harrowing & Increase $I_{3}$, by $220 \%$ & Sommers and Ersbell (1994) \\
Trail hose application & Reduce $a_{4}$ by $30 \%$ & Döhler (1990) and Bless $e t$ al. (1991) \\
Sod injection & Reduce $V_{4}$, TAN$_{4}$ and $D_{4}$ by $90 \%$ & Klarenbeek and Bruins (1991) \\
Deep injection & Reduce $V_{4}$, TAN $_{4}$ and $\mathrm{D}_{4}$ by $99.5 \%$ & Klarenbeek and Bruins (1991) \\
\hline
\end{tabular}

${ }^{2}$ Representative figures were taken from a few sources for demonstration purposes; an extensive review was not undertaken.

prior to application appears to reduce loss by increasing the infiltration rate (Sommer and Ersboll, 1994) whilst any reduction achieved by injection or postapplication cultivation is due to a reduction in the volume and area of slurry exposed to the atmosphere (e.g. van der Molen et al., 1990; Chardon et al., 1990). The relationships used within the model to simulate the effect of application/cultivation techniques are shown in Table 2.

Where cultivation does not occur immediately after application, the potential for reducing losses is decreased (Klarenbeek and Bruins, 1991) and losses must be partitioned between the pre- and postcultivation periods. This is achieved by separately simulating the losses for the periods before and after cultivation, using equations (B7) and (B8) (Appendix B).

\section{Applied slurry losses submodel}

Given that slurry applications can be $\mathrm{NH}_{3}$ sources for a number of days, the total $\mathrm{NH}_{3}$ loss from applied slurry on day $t$ is

$$
A_{4, t}=\sum_{b=1}^{t} A_{4, b, t}
$$

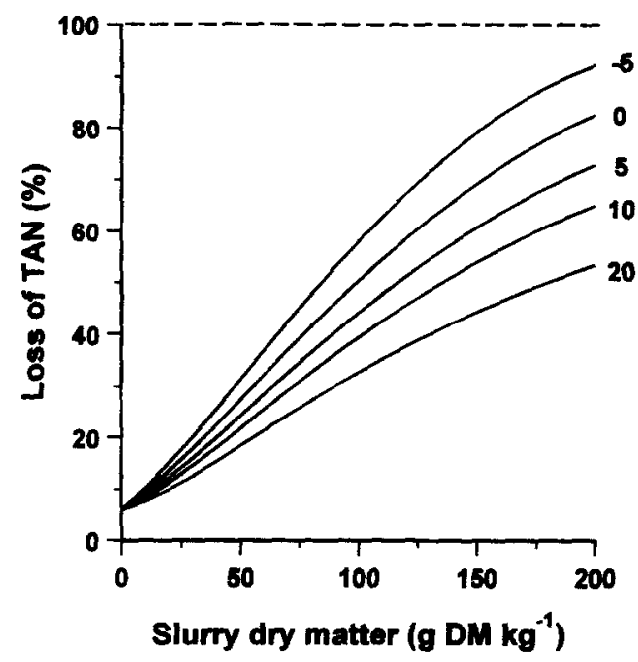

Fig. 2. The volatilization of $\mathrm{NH}_{3}$ as affected by dry matter in the slurry for five values of excess rainfall $\left(\mathrm{g} \mathrm{m}^{-2} \mathrm{~d}^{-1} \equiv \mathrm{mm} \mathrm{d}^{-1}\right)$. Initial values: TAN $=27 \mathrm{~g} \mathrm{~m}^{-2}$, volume applied $=3 \mathrm{~kg} \mathrm{~m}^{-2}, \mathrm{pH}=7.7$. Environment: soil infiltration $=230 \mathrm{~kg} \mathrm{~m}^{-2} \mathrm{~d}^{-1}$, air temperature $=15^{\circ} \mathrm{C}$, wind speed $=4 \mathrm{~m} \mathrm{~s}^{-1}$ and no cultivation. where $A_{4, b, t}$ is the volatilization on day $t$ from an application made on day $b$. Volatilization is followed until $V_{4, b, t}$ falls to zero or the $\operatorname{TAN}_{4, b, t}<10^{-7} \mathrm{~kg} \mathrm{~m}^{-2}$.

\section{Behaviour of submodel}

The behaviour of the applied slurry submodel is illustrated in Fig. 2. Note that the effect of varying the difference between rainfall and evaporation rate increases with increasing solids content of the slurry. In fact, for a slurry with no solids, rainfall and evaporation rate increase and decrease, respectively, the duration of volatilization, but if all other factors remain constant, neither has an effect on the cumulative loss from a given application.

\section{AMMONIA LOSSES FROM URINE PATCHES}

Ammonia losses from grazing animals vary with the environment (Whitehead and Raistrick, 1991) and with the level of fertilizer $\mathrm{N}$ applied (Jarvis et al., 1989; Bussink, 1990). In N. Europe, the proportion of N excreted during grazing that is volatilized is generally small (around $10 \%$ or less), but is significant in absolute terms as excretal $\mathbf{N}$ flows can be large (Scholefield et al., 1991).

The losses from urine patches are treated in the model as though they were slurry applications with a zero solids content. No allowance is made for the time taken for urea to hydrolyse to $\mathrm{NH}_{4}^{+}$. However, as with broad spread slurry, an amount $\eta$ is assumed to be intercepted by the grass crop and all the $\mathrm{NH}_{3}$ within it lost. There is good evidence that this makes an important contribution to losses from urine patches (Sherlock and Goh, 1985b; Whitehead and Raistrick, 1991). The urine contains no suspended solids so a time step of $1 \mathrm{~d}$ is used during the simulation.

\section{TOTAL LOSS FROM THE FARM}

The total $\mathrm{NH}_{3}$ loss from the farm $\left(A_{\mathrm{F}, t} ; \mathrm{kg} \mathrm{Nd}^{-1}\right)$ is

$$
A_{\mathrm{F} . t}=\sum_{i=1}^{5} A_{i, t} .
$$

The TAN, suspended solids and mass of water were tested for continuity to ensure all material input could be accounted for at the end of the simulation. 
Appropriate parameter values were either obtained from the literature or estimated by fitting submodel predictions to observed values. In each case, the data source is shown in Appendix A.

No attempt has been made to validate the model. Although estimates of farm emissions of $\mathrm{NH}_{3}$ based on $\mathrm{N}$ balance models are available (Jarvis, 1993), the authors are unaware of any data set that would allow the model to be validated at the farm scale. The presence within the housing and slurry store submodels of specific house and store factors precludes validation in these cases. The slurry/urine submodel could be validated if a data set could be obtained in which both $\mathrm{pH}$ and infiltration rate were measured over the duration of volatilization. The submodel predicts responses to environmental factors that agree qualitatively with those in the literature. The predictions are within the range of values found in the literature, but such is the breadth of that range that it would be difficult to do otherwise. There is an urgent need for simultaneous measurement of ammonia losses from the various on-farm sources over periods of weeks or months.

\section{EXAMPLE SIMULATIONS}

\section{Type of livestock system}

The model was used to simulate the $\mathrm{NH}_{3}$ loss from two contrasting types of livestock systems, beef cattle and dairy cows, under the same weather conditions. The quantity and quality of feed and animal growth or milk production for each system are shown in Table 3 and were based on examples given in SCA (1990). The stock number within the dairy system was chosen such that the annual $\mathrm{N}$ input to both systems was the same. The duration of the simulation was $1 \mathrm{yr}$, starting on 1 November and with an empty slurry store. Daily weather data were obtained for the Foulum Research Centre, Denmark, for 1991-1992; mean temperature $7.8^{\circ} \mathrm{C}$, total precipitation $730 \mathrm{~mm}$ and mean wind specd $3 \mathrm{~ms}^{-1}$. The evaporation ratc was equated to the potential evapotranspiration rate (annual total $405 \mathrm{~mm}$ ). During the grazing period (days 180 to 365 inclusive), the beef cattle were not housed whereas the dairy cows were housed for $8 \mathrm{~h} \mathrm{~d}^{-1}$.

The slurry utilization strategy aimed to simulate applications to spring and autumn sown cereal crops or spring grass whilst also encompassing a range of environmental conditions. Slurry applications were made within both systems at intervals of $5 \mathrm{~d}$ from day 200 (17 May) at a rate of $30 \mathrm{~m}^{3} \mathrm{ha}^{-1}$ until the slurry store was emptied (day 240 and day 225 for the beef and dairy systems, respectively). The first three applications in the spring were made to bare soil, the remainder to fields with a crop cover. Within the dairy system, the slurry that accumulated over the grazing period was fully utilized by further applications to bare soil, beginning on day 345 (10 October) and finishing on day 364 (30 October).

The $\mathrm{N}$ excretion per dairy animal $\left(121 \mathrm{~kg} \mathrm{~N} \mathrm{yr}^{-1}\right)$ was a little higher than the $108 \mathrm{~kg} \mathrm{~N} \mathrm{yr}^{-1}$ obtained from the regression equation of Kirchgessner $e t$ al. (1991). The equivalent value for the beef cattle $\left(40 \mathrm{~kg} \mathrm{Nyr}^{-1}\right)$ is intermediate between the figures for calves and young cattle found by Mandersloot (1992). The ammonia loss from the beef and dairy systems represented 10 and $21 \%$, respectively, of the $\mathrm{N}$ excreted. These are lower than the 24 and $27 \%$ calculated in ECETOC (1994), reflecting the higher dietary $\mathrm{N}$ concentration assumed in the latter report.

Over 6.5 times more $\mathrm{NH}_{3}$ was lost per dairy animal than per beef animal (Table 4a), emphasizing the need to disagreggate national animal numbers into different functional classes. The differences cannot be removed by using simple scaling factors such as intake or body size because they arise from systematic variations in animal intake, feed quality and farm management.

A greater proportion of the $\mathrm{N}$ input to the dairy system was lost than from the beef cattle system (Table 4a). Despite a greater export of $\mathrm{N}$ in milk than

Table 3. Characteristics of the example beef cattle and dairy systems

\begin{tabular}{lccc}
\hline & & Beef & Dairy \\
\hline Number & & 100 & 27.8 \\
Feed intake & $\mathrm{kganimal}^{-1} \mathrm{~d}^{-1}$ & 7.5 & 16.6 \\
Digestibility of feed & $\%$ & 70 & 75 \\
N in feed & $\%$ & 1.6 & 2.6 \\
Animal growth & $\mathrm{kganimal}^{-1} \mathrm{~d}^{-1}$ & 0.6 & 0 \\
Milk production & $\mathrm{kganimal}^{-1} \mathrm{~d}^{-1}$ & 0 & 18.8 \\
\hline
\end{tabular}

Characteristics common to both systems: housing: $a_{1} 3.3 \mathrm{~m}^{2}$ animal $^{-1}$, $\mathrm{pH}_{1, t} 8.0, V_{\mathrm{w}, t} 333 \mathrm{~kg} \mathrm{~d}^{-1}$, slurry transferred to store weekly; slurry store: $a_{2}$, $18.9 \mathrm{~m}^{2}, \mathrm{pH}_{2 . t} 7.7, a_{\mathrm{y}} 250 \mathrm{~m}^{2}$, no surface covering, filling location at top; spreading: $\Omega 0.02$, application: $\mathrm{pH}_{4, t} 7.7, I_{\mathrm{s}} 230 \mathrm{~kg} \mathrm{~m}^{-2}$, slurry applied by broad spreading, grazing: $\mathrm{pH}_{5, t} 8.0$.

Values for urine $\mathrm{pH}$ are intermediate between those of urine and urinetreated soil (Haynes and Williams, 1992) or slurry (Sommer and Olesen, 1991). The remaining values are derived from data in SAC (1989), Sommer and Olesen (1991) and Lilly (1994). 
Table 4. Predicted annual losses of $\mathrm{NH}_{3}-\mathrm{N}$ from the two livestock farming systems described in Table 3

(a) Total annual inputs, outputs and losses for each system

\begin{tabular}{lccccccc}
\hline System & $\begin{array}{c}\mathrm{N} \text { input } \\
\text { per animal } \\
(\mathrm{kg})\end{array}$ & $\begin{array}{c}\text { Total } \mathrm{N} \\
\text { input } \\
(\mathrm{kg})\end{array}$ & $\begin{array}{c}\mathrm{N} \text { in } \\
\text { milk/tissue } \\
(\mathrm{kg})\end{array}$ & $\begin{array}{c}\text { TAN } \\
\text { excreted } \\
(\mathrm{kg})\end{array}$ & $\begin{array}{c}\mathrm{NH}_{3}-\mathrm{N} \\
\text { lost } \\
(\mathrm{kg})\end{array}$ & $\begin{array}{c}\% \text { of } \mathrm{N} \\
\text { input } \\
\text { lost }\end{array}$ & $\begin{array}{c}\text { Loss per } \\
\text { animal } \\
(\mathrm{kg})\end{array}$ \\
\hline Beef & 44 & 4380 & 416 & 1869 & 484 & 11.0 & 4.2 \\
Dairy & 138 & 4379 & 1011 & 2299 & 710 & 16.2 & 25.5 \\
\hline
\end{tabular}

(b) Distribution of losses

\begin{tabular}{lccccc}
\hline & \multicolumn{4}{c}{ Ammonia source (\%) } \\
\cline { 2 - 5 } System & Grazing & House & Storage & Spreading & Applied \\
\hline Beef & 25 & 9 & 28 & 3 & 36 \\
Dairy & 14 & 7 & 47 & 3 & 29 \\
\hline
\end{tabular}

Table 5. Effect of applying control measures on $\mathrm{NH}_{3}$ losses from the beef cattle and dairy systems

\begin{tabular}{|c|c|c|c|c|c|c|}
\hline \multirow[b]{2}{*}{ Control measure } & \multicolumn{6}{|c|}{$\begin{array}{l}\text { Ammonia losses } \\
\text { (as percentage of losses without control measures) }\end{array}$} \\
\hline & Grazing & House & Storage & Spreading & Applied & Total loss \\
\hline \multicolumn{7}{|l|}{ Beef } \\
\hline$A$ & 100 & 68 & 102 & 107 & 101 & 98 \\
\hline B & 100 & 100 & 41 & 114 & 111 & 84 \\
\hline $\mathrm{C}$ & 100 & 100 & 33 & 114 & 162 & 104 \\
\hline D & 100 & 100 & 100 & 0 & 9 & 64 \\
\hline$A+C+D$ & 100 & 68 & 33 & 0 & 15 & 45 \\
\hline \multicolumn{7}{|l|}{ Dairy } \\
\hline A & 100 & 70 & 101 & 100 & 101 & 99 \\
\hline $\mathrm{B}$ & 100 & 100 & 53 & 113 & 113 & 83 \\
\hline $\mathrm{C}$ & 100 & 100 & 55 & 113 & 189 & 106 \\
\hline D & 100 & 100 & 100 & 0 & 9 & 70 \\
\hline$A+C+D$ & 100 & 70 & 56 & 0 & 19 & 51 \\
\hline
\end{tabular}

Control measure: A, reduce floor and store surface area per animal from 3.3 to $2.3 \mathrm{~m}^{2}$; $\mathrm{B}$, cover slurry storage with expanded clay; C, cover slurry storage with lid; D, apply slurry by sod injection.

in animal tissue, the higher quality of feed used in the dairy system meant a greater proportion of the feed $\mathrm{N}$ was excreted as TAN. In addition, a greater proportion of this TAN was lost from the dairy than from the beef system $(33 \%$ vs $26 \%)$. The TAN can pass to the soil via two routes: deposition as urine during grazing or through the slurry handling system. The latter offers greater opportunities for $\mathrm{NH}_{3}$ loss owing to prolonged exposure of the slurry surface in the animal housing, storage and after application. The beef cattle were not housed during the summer so the slurry handling system was inactive, lowering its contribution to the total loss (Table $4 \mathrm{~b}$ ). In contrast, the dairy slurry handling system was active throughout a period when the environmental conditions for volatilization were most favourable.

\section{Effectiveness of control measures}

The losses from animal housing can be reduced by altering the design and management of the housing (e.g. Groenestein, 1994) whilst those from storage can be reduced by covering the slurry store (e.g. de Bode, 1991; Sommer et al., 1993). The effectiveness of both methods was tested (Table 5). Effective reductions in the losses from animal housing or slurry storage were less effective in reducing losses from the whole system. In most cases, this was because the reduction in loss led to an increase in the concentration of TAN in the slurry so there was an increase in losses from subsequent sources.

The consequences of using a lid on the slurry store were more complex. In this case, in addition to retaining more TAN in the slurry, the lid prevented rainwater entering. This raised the solids concentration in the slurry and, at the time of application, reduced the rate of infiltration into the soil. The effect of this was to increase volatilization from the applied slurry so the use of a lid on the slurry store had little impact on the total loss from the whole system.

Slurry injection was the most effective single method of reducing losses; proportionately more so in the beef than the dairy system because losses after application were of greater importance. Even greater 
reductions were possible when a combination of scveral control methods was used, although the difference between the beef and dairy systems persisted.

These interactions between $\mathbf{N H}_{3}$ sources highlight the need to consider the fate of excreta at a farm level when assessing the effectiveness of control measures.

\section{CONCLUSIONS}

The substantially greater loss of $\mathrm{NH}_{3}$ per animal from dairy cattle than from beef cattle emphasizes the need to distinguish between different classes of animal when calculating losses on a farm, region or national scale. The use of dynamic models such as the present one is a means by which emission factors can be amended. The model highlights the complex interactions that occur within and between the various sources of $\mathrm{NH}_{3}$ on livestock farms. These interactions will modify the effectiveness of control measures and the model clearly demonstrates that it is important to consider the fate of excreta at a farm level when assessing such measures.

The model requires improvement, particularly to the simulation of losses from housing, of chemical transformations within the urine and slurry and of slurry infiltration. A sensitivity analysis and a review of parameter values are required. Inclusion of the losses that occur from solid manures is also a priority as many livestock farms still handle animal wastes in this form. All the control methods considered led to an increase in $\mathrm{NH}_{4}^{+}$entering the soil. This $\mathrm{NH}_{4}^{+}$will enter the soil $\mathbf{N}$ cycle and increase the potential for other pollution, e.g. $\mathrm{NO}_{3}$ leaching or loss of $\mathrm{N}_{2} \mathrm{O}$ to the atmosphere. This emphasizes the need to adopt a holistic approach to farm $\mathrm{N}$ management.

Acknowledgements-This work was funded by the Scottish Office Department of Agriculture and Fisheries, Edinburgh, the Ministry of Environment, Copenhagen, and the Ministry of Agriculture, Fisheries and Food, London.

\section{REFERENCES}

ApSimon H. M., Kruse M. and Bell N. J. B. (1987) Ammonia emissions and their role in atmospheric deposition. Atmospheric Environment 21, 1939-1946.

Asman W. A. H. and van Jaarsveld H. A. (1991) A variable resolution transport model applied for $\mathbf{N H}_{x}$ in Europe. Atmospheric Environment 26A, 445-464.

Beauchamp E. G., Kidd G. E. and Thurtell G. (1982) Ammonia volatilization from liquid dairy cattle manure in the field. Can. J. Soil Sci. 62, 11-19.

Bless H. G., Beinhauer R. and Sattelmacher B. (1991) Ammonia emission from slurry applied to wheat stubble and rape in North Germany. J agric. Sci., Camb. 117, 225-231.

Boxberger J. and Gronauer A. (1990) $\mathrm{NH}_{3}$-emission während der flüssigmistaus bringung. In Ammoniak in der umwelt. Kreisläufe, wirkungen, minderung (edited by Döhler H. and Van den Weghe H.), pp. 42.1-42.5. KTBL-Schriften-Vertrieb im Landwirtschafts verlag $\mathrm{GmbH}$, MünsterHiltrup, Germany.
Buijsman E., Maas H. F. M. and Asman W. A. H. (1987) Anthropogenic $\mathbf{N H}_{3}$ emissions in Europe. Atmospheric Environment 21, 1009-1022.

Burton D. L. and Beauchamp E. G. (1986) Nitrogen losses from swine housings. Agric. Wastes 15, 59-74.

Bussink D. W. (1990) Ammonia volatilization from a rotationally grazed sward. I. Effects of management on annual losses. In Fertilization and the Environment (edited by Merckx R. et al.), pp. 305-323. Leuven University Press, Leuven.

Chardon W. J., van der Molen, J. and van Faassen H. G. (1990) Modelling ammonia emissions from arable land. In Ammonia and Odour Emission from Livestock Production (edited by Neilsen V. C., Pain B. F. and Hartung J.), pp. 156-165. CEC, Brussels.

de Bode M. J. C. (1991) Odour and ammonia emissions from manure storage. In Ammonia and Odour Emissions from Livestock Production (edited by Nielsen V. C., Voorburg J. H. and L'Hermité P.), pp. 59-66. Elsevier Applied Science, London

Dickinson C. H. and Craig G. (1990) Effects of water on the decomposition and release of nutrients from cow pats. New Phytologist 115, 139-147.

Döhler H. (1990) Laboratory and field experiments for estimating ammonia losses from pig and cattle slurry following application. In Ammonia and Odour Emission from Livestock Production (edited by Neilsen V. C., Pain B. F. and Hartung J.), pp. 132-140. CEC, Brussels.

ECETOC (1994) Ammonia emissions to air in Western Europe. Technical Report No. 62, pp. 1-196. ECETOC, Brussels.

Groenestein C. M. (1994) Animal-waste management and emission of ammonia from livestock housing systems: field studies. In Livestock Environment IV, 4th Int Symp., University of Warwick, pp. 1169-1175. American Society of Agricultural Engineers, St Joseph, Michigan.

Hansen J. F., Olesen J. E., Munk I., Henius U. M., Høy, J. J., Rude S., Steffensen M., Huld T., Guul-Simonsen F., Danfaer A., Boisen S. and Mikkelsen S. A. (1990) Nitrogen in animal manure. Beretning No. S2100-1990, pp. 1-127. Danish Institute of Plant and Soil Science (in Danish).

Haynes R. J. and Williams P. H. (1992) Changes in soil solution composition and $\mathrm{pH}$ in urine-affected areas of pasture. J. Soil Sci. 43, 323-334.

Husted S., Jensen L. S. and Jørgensen S. S. (1991) Reducing ammonia loss from cattle slurry by the use of acidifying additives: the role of the buffer system. J. Sci. Fd Agric. 57, 335-349.

Janssen J. and Krause K.-H. (1990) Messun und simulation von ammoniak koncentrationen in ställen. In Ammoniak in der umwelt (edited by Döhler $\mathrm{H}$. and van den Weghe $\mathrm{H}$.), pp. 21.1-21.12. KTBL-Schriften-Vertrieb im Landwirtschaftsverlag GmbH, Münster-Hiltrup.

Jarvis S. C. (1993) Nitrogen cycling and losses from dairy farms. Soil Use Management 9, 99-105.

Jarvis S. C. and Pain B. F. (1990) Ammonia volatilization from agricultural land. Proc. No. 298, p. 35. The Fertiliser Society, London.

Jarvis S. C., Hatch D. J. and Robcrts D. H. (1989) The effects of grassland management on nitrogen losses from grazed swards through ammonia volatilization; the relationship to excretal N returns from cattle. J, agric. Sci., Camb. 112, 205-216.

Jarvis S. C., Hatch D. J. and Lockyer D. R. (1991) Micrometeorological studies of ammonia emission from grazed swards. J. agric. Sci., Camb. 117, 101-109.

Kirchgessener M., Windisch W. and Kreuzer M. (1991) Stikstoffemission laktierender Milschkuhe uher die Gulle in Abhangigkeit von der Leistungsintensitat. Agrobiol. Res. 44, 1-13.

Klarenbeek J. V. and Bruins M. A. (1991) Ammonia emission after land spreading of animal slurries. In Ammonia and Odour Emissions from Livestock Production (edited by 
Nielsen V. C., Voorburg J. H. and L'Hermité P.), pp. 107-115. Elsevier Applied Science, London.

Lee D. S. and Dollard G. J. (1994) Uncertainties in current estimates of cmissions of ammonia in the United Kingdom. Envir. Poll. 86, 267-277.

Lilly A. (1994) The determination of field-saturated hydraulic conductivity in some Scottish soils using the Guelph permeameter. Soil Use Management 10, 72-78.

Mandersloot F. (1992) Bedrijfseconomishe gevolgen beperking stikstofverliezen op melkveebedrijven. Report 138, Proefstation voor de Rundveehouderij Schapenhouderij en Paardenhouderij, Lelystad.

Mannebeck H. and Oldenburg J. (1991) Comparison of the effect of different systems on ammonia emissions. In Odour and Ammonia Emissions from Livestock Farming (edited by Nielsen V.C. Voorburg J. H. and L'Hermité P.), pp. 42-49. Elsevier Applied Science, London.

Muck R. E. and Richards B. K. (1983) Losses of manurial nitrogen in free-stall barns. Agric. Wastes 7, 65-79.

Olesen J. E. and Sommer S. G. (1994) Modelling effects of wind speed and surface cover on ammonia volatilization from stored pig slurry. Atmospheric Entironment 27, 2567-2574.

Oosthoek J., Kroodsma W. and Hoeksma P. (1990) Betrieblichemassnahme zur minderung von ammoniakemissionen aus ställen. In Ammoniak in der umwelt (edited by Döhler H. and van den Weghe H.), pp. 29.1-29.23. KTBL-Schriften-Vertrieb im Landwirtschaftsverlag GmbH, Münster-Hiltrup.

Oosthoek J., Kroodsma W. and Hoeksma P. (1991) Ammonia emission from dairy and pig housing systems. In Odour and Ammonia Emissions from Livestock Farming (edited by Nielsen V. C., Voorburg J. H. and L'Hermité P.), pp. 31-41. Elsevier Applied Science, London.

Pain B. F., Phillips V. R., Clarkson C. R. and Klarenbeek J. V. (1989) Loss of nitrogen through ammonia volatilisation during and following application of pig or cattle slurry to grassland. $J$ Sci. Fd Agric., 47, 1-12.

Phillips V. R., Pain B. F. and Klarenbeek J. V. (1991) Factors affecting the odour and ammonia emissions during and after land spreading of animal slurries. In Ammonia and Odour Emissions from Livestock Production (edited by Nielsen V. C., Voorburg J. H. and L'Hermité P.), pp. 98-106. Elsevier Applied Science, London.

SAC (1989) In Farm Management Handbook 1989/90 (edited by Chadwick L.). Scottish Agricultural Colleges, Edinburgh.

SCA (1990) Feeding Standards for Australian Livestock. Ruminants, pp. 1-266. CSIRO Publications, East Melbourne, Victoria.

Scholefield D., Lockyer D. R., Whitehead D. C. and Tyson K. C. (1991) A model to predict transformations and losses of nitrogen in U.K. pastures by beef cattle. Plant Soil 132, 165-177.

Schulze E.-D., De Vries W., Hauhs M., Rosén K., Rasmussen L., Tamm C.-O. and Nilsson J. (1989) Critical loads for nitrogen deposition on forest ecosystems. Wat. Air Soil Poll. 48, 451-456.

Sherlock R. R. and Goh K. M. (1985a) Dynamics of ammonia volatilization from simulated urine patches and aqueous urea applied to pasture. II. Theoretical derivation of simplified model. Fertilizer Res 6, 3-22.

Sherlock R. R. and Goh K. M. (1985b) Dynamics of ammonia volatilization from simulated urine patches and aqueous urea applied to pasture. III. Field verification of a simplified model. Fertilizer Res. 6, 23-36.

Sommer S. G. (1989) Spreading of slurry: volatilization of ammonia and distribution of applied slurry. Tidskr. Planteavl. 93, 323-329 (in Danish; summary and legends in English).

Sommer S. G. and Olesen J. E. (1991) Effect of dry matter content and temperature on ammonia loss from surfaceapplied cattle slurry. J. Envir. Qual. 20, 679-683.
Sommer S. G. and Ersbøll S. K. (1994) Soil tillage effects on ammonia volatilisation from surface applied or injected animal slurry. J. Envir. Qual. 23, 493-498.

Sommer S. G., Olesen J. E. and Christensen B. T. (1991) Effects of temperature, wind speed and air humidity on ammonia volatilization from surface applied cattle slurry. J. agric. Sci., Camb. 117, 91-100.

Sommer S. G., Christensen B. T., Nieisen N. E. and Schjørring, J. K. (1993) Ammonia volatilization during storage of cattle and pig slurry: effect of surface cover. J. agric. Sci., Camb. 121, 63-71.

Svensson L. (1994) Ammonia volatilization following application of livestock manure to arable land. I. agric. Engng Res. 58, 241-260

Van de Ven, G. W. J. (1992) Grasmod, a grassland management model to calculate nitrogen losses from grassland, pp. 1-109. Centre for Agrobiological Research, Wageningen.

van der Molen J., Beiljaars A. C., Chardon W. J., Jury W. A. and van Faassen H. G. (1990) Ammonia volatilization from arable land after application of cattle slurry. 2. Derivation of a transfer model. Neth. J. agric. Sci. 38, 239-254.

Voorburg J. H. and Kroodsma W. (1992) Volatile emissions of housing systems for cattle. Livestock Proc. Sci. 31, $57-70$.

Whitehead D. C. and Raistrick N. (1991) Effects of some environmental factors on ammonia volatilization from simulated livestock urine applied to soil. Biology Fertility Soils 11, 279-284.

\section{APPENDIX A: NOMENCLATURE}

Variables subscripted $t$ are the values on day $t$. Variables subscripted $\mathrm{x}$ are the values for $\mathrm{NH}_{3}$ source number $x$ where source number 1 = animal housing, $2=$ stored slurry, $3=$ losses during application, $4=$ applied slurry and $5=$ urine patches.

$A_{x, r} \quad \mathrm{NH}_{3}$ volatilization from source $\times\left(\mathrm{kg} \mathrm{Nd}^{-1}\right)$

$A_{\mathrm{F}, \mathrm{r}}$ total loss of $\mathrm{NH}_{3}$ from the farm $\left(\mathrm{kg} \mathrm{N} \mathrm{d}^{-1}\right)$

State variables

TAN $_{x, 1}$ mass of TAN $\left(\mathrm{kg} \mathrm{m}^{-2}\right)$

TAN $_{x, b, t}$ mass of TAN within slurry $(x=4)$ or urine

$(x=5)$ deposited on day $b\left(\mathrm{~kg} \mathrm{~m}^{-2}\right)$

$V_{x, t}, V_{x, b, t}$ as above but for the wet weight of slurry or

$D_{x, t}, D_{x, b} \quad$ as above but for the dry weight of slurry solids $\left(\mathrm{kg} \mathrm{m}^{-2}\right)$

$\mathrm{pH}_{x, t}, \mathrm{pH}_{x, b}$ as above but for $\mathrm{pH}$

$a_{x, t} \quad$ surface area of source $\left(\mathrm{m}^{2}\right)$

\section{Model inputs}

$\alpha_{\mathrm{s}}$ apparent digestibility of animal feed $\left(\operatorname{kgDM}\left(\mathrm{kg} \mathrm{DM}^{-1}\right)\right.$

$\theta_{t} \quad$ outside air temperature $\left({ }^{\circ} \mathrm{C}\right)$

$a_{y} \quad$ area of roofing and yard that contributes water to the slurry $\left(\mathrm{m}^{2}\right)$

$c_{\mathrm{h}, \mathrm{f}}$ nitrogen concentration in the feed supply $\left(\mathrm{kg} \mathrm{N}(\mathrm{kg} \mathrm{DM})^{-1}\right)$

$E_{\ell} \quad$ evaporation rate $\left(\mathrm{kg} \mathrm{m}^{-2} \mathrm{~d}^{-1}\right)$

$F_{t}$ quantity of feed eaten per animal (kg DM ani$\mathrm{mal}^{-1} \mathrm{~d}^{-1}$ )

$H_{\mathrm{r}} \quad$ proportion of the day during which the animals are housed

$I_{5} \quad$ soil infiltration rate $\left(\mathrm{kg} \mathrm{m}^{-2} \mathrm{~d}^{-1}\right)$

$K_{t} \quad$ empty body weight gain $\left(\mathrm{kg} \mathrm{d}^{-1}\right)$

$M_{\mathrm{t}} \quad$ milk yield $\left(\mathrm{kg}\right.$ animal $\left.{ }^{-1} \mathrm{~d}^{-1}\right)$

$p_{i} \quad$ precipitation rate $\left(\mathrm{kg} \mathrm{m}^{-2} \mathrm{~d}^{-1}\right)$

$R_{1, t}$ mass of manure removed from the animal housing $(\mathrm{kg})$ 
$R_{2, t}$ mass of slurry removed from the slurry store to be applied to land $(\mathrm{kg})$

$S_{t} \quad$ number of animals on the farm

\section{Parameters and secondary variables}

$\beta \quad$ water content of faeces $\left(\mathrm{kg}(\mathrm{kg} \mathrm{DM})^{-1}\right)=6.9^{*}$

$\gamma \quad$ specific weight of slurry $\left(\mathrm{kg} \mathrm{m}^{-3}\right)=1000$

$\varepsilon \quad$ volatilization rate parameter $\left(\mathrm{kg} \mathrm{m}^{-2} \mathrm{~d}^{-1}\right)$, equation (B10)

$\lambda$ dry matter added in bedding and spilt feed $\left(\mathrm{kg} \mathrm{DM}\right.$ animal $\left.{ }^{-1} \mathrm{~d}^{-1}\right)=0.96^{* *}$

$\eta \quad$ interception of slurry or urine by crop $\left(\mathrm{kg} \mathrm{m}^{-2}\right)=0.2 \dagger$

$\Omega \quad$ proportion of slurry or urine TAN lost during spreading $=0.02$

$\zeta, \mu \quad$ constants determining the effect of slurry solids on infiltration

$c_{\mathrm{f}}$ concentration of nitrogen in faeces $\left(\mathrm{kg} \mathrm{N}(\mathrm{kg} \mathrm{DM})^{-1}\right)=0.025^{*}$

$c_{\mathrm{m}}$ concentration of nitrogen in milk $\left(\mathrm{kg} \mathrm{N}(\mathrm{kg} \mathrm{DM})^{-1}\right)=0.0053 \ddagger$

$c_{*} \quad$ concentration of nitrogen in new animal tissue $\left(\mathbf{k g ~ N}(\mathrm{kg} \text { tissue })^{-1}\right)=0.024 \ddagger$

$D_{f, t}$ daily faecal dry matter output of the animals $\left(\mathrm{kg} \mathrm{DM} \mathrm{d} \mathrm{d}^{-1}\right)$

$I_{b, j} \quad$ infiltration rate during the $j$ th time step within an area that received slurry on day $b\left(\mathrm{~kg} \mathrm{~m}^{-2} \mathrm{~d}^{-1}\right)$

$I_{\mathrm{m}} \quad$ minimum infiltration rate $\left(\mathrm{kg} \mathrm{m}^{-2} \mathrm{~d}^{-1}\right)$

$I_{t} \quad$ infiltration rate $\left(\mathrm{kg} \mathrm{m}^{-2} \mathrm{~d}^{-1}\right)=0.02$

$N_{\text {f.t }} \quad$ faecal nitrogen production $\left(\mathrm{kg} \mathrm{N} \mathrm{d}^{-1}\right)$

$N_{u, t} \quad$ urinary nitrogen production $\left(\mathrm{kg} \mathrm{N} \mathrm{d}^{-1}\right)$

$Q_{x, t}$ value of the equilibrium coefficient (equation (2))

$r_{1, t}$ resistance to $\mathrm{NH}_{3}$ transport from the animal housing to the atmosphere $\left(\mathrm{d} \mathrm{m}^{-1}\right)$

$r_{2, t}$ resistance to $\mathrm{NH}_{3}$ transport from the slurry store to the atmosphere $\left(\mathrm{d} \mathrm{m}^{-1}\right)$

$r_{\mathrm{a}, t}$ aerodynamic resistance $\left(\mathrm{d} \mathrm{m}^{-1}\right)$

$r_{b, t} \quad$ boundary layer resistance $\left(\mathrm{d} \mathrm{m}^{-1}\right)$

$r_{c, i} \quad$ resistance of the $i$ th slurry surface covering in the slurry store $\left(\mathrm{s} \mathrm{m}^{-1}\right)$

$r_{\mathrm{T}} \quad$ store-specific resistance $\left(\mathrm{d} \mathrm{m}^{-1}\right)=0.000301 \S$

$u_{\mathrm{f}}$ urination frequency (urinations animal ${ }^{-1}$ $\left.\mathrm{d}^{-1}\right)=129$

$u_{\mathrm{r}} \quad$ urination rate $\left(\mathrm{kg}\right.$ urination $\left.{ }^{-1}\right)=1.6^{8}$

$u_{\mathrm{a}} \quad$ area of a single urine patch $\left(\mathrm{m}^{2}\right)=0.68^{4}$

$V_{u, t}$ mass of urine produced $\left(\mathrm{kg} \mathrm{d}^{-1}\right)$

$V_{t, t}^{u, t}$ mass of water in faeces $\left(\mathrm{kgd}^{-1}\right)$

$V_{\mathrm{w}, t}$ water used in animal housing for washing animals or flushing $(\mathrm{kg})=333$

$V_{y, t}$ roof and yard runoff $\left(\mathrm{kg} \mathrm{d}^{-1}\right)$

$X_{1}^{y, t} \quad$ housing-specific constant $=0.00843^{* *}$

Data sources: *Dickinson and Craig (1990), †Sherlock and Goh (1985b), †SCA (1990), §Olesen and Sommer (1994), ๆvan de Ven (1992), \#Hansen et al. (1990), **Mannebeck and Oldenburg (1990).

\section{APPENDIX B: THE TIME COURSE OF $\mathrm{NH}_{3}$ LOSS IN SLURRY APPLICATIONS AND URINE PATCHES}

The rate of change of TAN present in the slurry/urine remaining on the soil surface $\left(\mathrm{TAN}_{x} ; \mathrm{kg} \mathrm{m}^{-2}\right)$ can be described as

$$
\frac{\mathrm{dTAN}_{x}}{\mathrm{~d} t}=-\frac{Q_{x} y}{r_{x}} \frac{\operatorname{TAN}_{x}}{V_{x}}-I \frac{\operatorname{TAN}_{x}}{V_{x}}
$$

where $I=$ infiltration rate $\left(\mathrm{kg} \mathrm{m}^{-2} \mathrm{~d}^{-1}\right)$ and the remaining parameters are defined as in equation (1). To improve clarity, let

$$
\varepsilon=\frac{Q_{x} \gamma}{r_{x}}
$$

Rearranging equation (B1) gives

$$
\frac{1}{\operatorname{TAN}_{x}} \mathrm{dTAN}_{x}=-\frac{(\varepsilon+I)}{V_{x}} \mathrm{~d} t .
$$

The volume $\left(V_{x, t} ; \mathrm{m}^{-2}\right)$ changes due to infiltration, evaporation and rainfall and at time $t$

$$
V_{x, t}=V_{x, 0}-(I+E-p) t
$$

where $V_{x 0}$ is the mass at time $t=0, p=$ precipitation rate $\left(\mathrm{kg} \mathrm{m}^{-2} \mathrm{~d}^{-1}\right)$ and $E=$ evaporation rate $\left(\mathrm{kg} \mathrm{m}^{-2} \mathrm{~d}^{-1}\right)$. Substituting for $V_{x}$ in equation (B3) and integrating gives

$$
\begin{aligned}
\operatorname{TAN}_{x, \mathrm{t}} & =K\left(V_{x, 0}-(I+E-p) t\right)^{(\varepsilon+I) /(I+E-p)} \\
K & =\operatorname{TAN}_{x, 0}\left(V_{x, 0}\right)^{-((\varepsilon+I) /(I+E-p))}
\end{aligned}
$$

where $\operatorname{TAN}_{x, 0}$ is the TAN present at time $t=0\left(\mathrm{~kg} \mathrm{~m}^{-2}\right)$.

Volatilization and infiltration can be rapid so the loss on each day is simulated using $J$ small time steps of duration $\delta t$ $=0.01 \mathrm{~d}$. The volatilization during the $j$ th time step of day $t$ from slurry $(x=4)$ or urine $(x=5)$ applied on day $b$ $\left(A_{x, b, t, j} ; \mathrm{kg} \mathrm{Nd}^{-1}\right)$ is:

when $\left(I_{b, t, j}+E_{t}-p_{t}\right)=0$

$$
\begin{aligned}
A_{x, b, t, j}= & a_{x, b} \frac{\varepsilon}{\varepsilon+I_{b, t, j}} \operatorname{TAN}_{x, b, t, j} \\
& \times\left(1-\exp \left(-\varepsilon+I_{b, t, j} / V_{x, b, t, j} \delta t\right)\right)
\end{aligned}
$$

otherwise

$$
\begin{aligned}
& A_{x, b, t, j}=a_{x, b} \frac{\varepsilon}{\varepsilon+I_{b, t, j}}-\operatorname{TAN}_{x, b, t, j}\left(1-\operatorname{cxp}^{K_{n, t}}\right.
\end{aligned}
$$

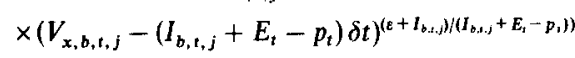

where $a_{x, b}$ is the area of application/deposition made on day $b\left(\mathrm{~m}^{2}\right), \mathrm{TAN}_{x, b, t, j}, V_{x, b, t, j}$ and $I_{b, t, j}$ are, respectively, the TAN present above the soil surface $\left(\mathrm{kg} \mathrm{m}^{-2}\right)$, the mass of slurry/urine above the soil surface $\left(\mathrm{kg} \mathrm{m}^{-2}\right)$ and the infiltration rate $\left(\mathrm{kg} \mathrm{m}^{-2} \mathrm{~d}^{-1}\right)$ at the beginning of the $j$ th time step for applications/depositions made on day $b . E_{t}$ and $p_{t}$ are, respectively, the evaporation and precipitation rate on day $t\left(\mathrm{~kg} \mathrm{~m}^{-2} \mathrm{~d}^{-1}\right) . \varepsilon$ and $K_{b, t, j}$ are defined as

$$
\begin{gathered}
\varepsilon=\frac{Q_{x, b, t} \gamma}{I_{x, t}} \\
K_{b, \boldsymbol{t}, j}=\ln \left(\operatorname{TAN}_{x, b, t, j}\left(V_{x, b, t, j}\right)^{-\left(\left(\varepsilon+I_{b, t, j}\right)\left(I_{b, t, j}+E_{t}-p_{t}\right)\right)}\right) .
\end{gathered}
$$

If $V_{b, t, j+1}$ falls to or below zero during a time step, then

$$
A_{4, b, t, j+1}=\frac{\varepsilon}{\varepsilon+I_{b, t, j}} a_{4, b} \mathrm{TAN}_{4, b, t, j}
$$

and no further volatilization takes place.

The infiltration rate in the absence of slurry solids is determined by that of the soil $\left(I_{s} ; \mathrm{kg} \mathrm{m}^{-2} \mathrm{~d}^{-1}\right)$. In reality, volatilization has been observed to increase with the concentration of slurry solids as increasing viscosity reduces infiltration (Sommer and Olesen, 1991; Svensson, 1994). The infiltration rate is assumed to be limited either by the soil or the slurry:

$$
I_{b, t, j}=\min \left(I_{\mathrm{s}}, I_{\mathrm{c}}\right)
$$

where $I_{c}$ is the infiltration rate determined by the slurry $\left(\mathrm{kg} \mathrm{m}^{-2} \mathrm{~d}^{-1}\right)$. The relationship between slurry composition and viscosity is poorly understood so $I_{c}$ is related directly to 
the concentration of solids in $V_{4}$ :

$$
I_{c}=\exp \left(\xi-\mu \frac{D_{4, b}}{V_{4, b, t, j}+D_{4, b}}\right)
$$

where $\zeta$ and $\mu$ are constants. It is assumed that the solids in the slurry remain on the soil surface. Using data from Sommer and Olesen (1991), $\zeta$ and $\mu$ were evaluated as 6.950 and 31.9 , respectively. With these parameter values, the infiltration rate approaches zero when the solids concentration is high, leading to excessive expenditure of time simulating the low rate of loss that occurs as the slurry TAN nears exhaustion. This was overcome by constraining $I_{c}$ to be $\geqslant I_{\mathrm{m}}$, an arbitrary minimum infiltration rate.

The resistance to transport $\left(r_{4, t}\right)$ is simulated in the manner outlined for losses from slurry stores, omitting the cover resistance. The equilibrium coefficient is calculated with the temperature equated to air temperature whilst the $\mathrm{pH}$ is assumed to be that of the slurry/urine at the time of application

Volatilization on day $t$ from applications made on day $b\left(A_{4, b, 1} ; \mathrm{kg} \mathrm{d}^{-1}\right)$ is then

$$
A_{4, b, t}=\sum_{j=1}^{J} A_{4, b, t, j} .
$$

Initial values for slurry applications

The masses of slurry, TAN and suspended solids are defined at the time of application, when $b=t$ and $a_{4, b}=a_{3, i}$ :

$$
\begin{gathered}
\operatorname{TAN}_{4, b, b, 0}=\frac{1}{a_{4, b}}\left(\frac{R_{2, b} \operatorname{TAN}_{2, b}}{V_{2, b}} A_{3, b}\right), \\
V_{4, b, b, 0}=\frac{R_{2, b}}{a_{4, b}} \\
D_{4, b}=\frac{R_{2, b} D_{2, b}}{a_{4, b} V_{2, b}} .
\end{gathered}
$$

The $\mathrm{pH}$ of the slurry is an input to the model.

Initial values for urine depositions

The initial conditions are

$$
\begin{gathered}
a_{5, b}=\left(1-H_{b}\right) S_{b} u_{\mathrm{f}} u_{a}, \\
\operatorname{TAN}_{5, b, b, 0}=\frac{\left(1-H_{b}\right) N_{\mathrm{u}, b}}{a_{5, b}}, \\
V_{5, b, b, 0}=\frac{\left(1-H_{b}\right) S_{b} u_{\mathrm{r}} u_{f}}{a_{5, b}}, \quad D_{5, b}=0
\end{gathered}
$$

where $u_{\mathrm{a}}$ is the area of a single urine patch $\left(\mathrm{m}^{2}\right)$.
The $\mathrm{pH}$ of the urine is an input to the model. The aerodynamic resistance is calculated assuming the emitting surface has an area of $u_{\mathrm{a}}$.

\section{APPENDIX C: BUDGETS FOR TAN, WATER AND DRY MATTER}

Budgets for the TAN $\left(\operatorname{TAN}_{x, z}\right)$, water $\left(V_{x, t}\right)$ and dry matter $\left(D_{x, s}\right)$ are as follows.

Housing, $x=1$

$$
\begin{array}{r}
\operatorname{TAN}_{1, t+1}=\operatorname{TAN}_{1, t}\left(1-\frac{R_{1, t}}{V_{1, t}}\right)+\frac{\left(H_{t} N_{\mathrm{u}, t}-A_{1, t}\right)}{a_{1}} \\
V_{1, t+1}=V_{1, t}+\frac{1}{a_{1}}\left(H_{t}\left(V_{\mathrm{u}, t}+V_{\mathrm{f}, t}\right)+V_{\mathrm{w}, t}-R_{1, t}\right) \\
D_{1, t+1}=D_{1, t}\left(1-\frac{R_{1, t}}{V_{1, t}}\right)+\frac{H_{t} D_{\mathrm{f}, t}+\lambda S_{\mathrm{t}}}{a_{1}}
\end{array}
$$

where $R_{1, t}$ is the volume of manure removed at time $t(\mathrm{~kg})$ and $\lambda$ is the dry matter added in bedding and spilt feed $\left(\mathrm{kg} \mathrm{DM}_{\text {animal }}{ }^{-1} \mathrm{~d}^{-1}\right.$ ).

Storage, $x=2$

$$
\begin{array}{r}
\operatorname{TAN}_{2, t+1}=\mathrm{TAN}_{2, t}+\frac{1}{a_{2}}\left(\frac{R_{1, t} \mathrm{TAN}_{1, t}}{V_{1, t}}\right. \\
\left.-\left(A_{2, t}+\frac{R_{2, t} \mathrm{TAN}_{2, t}}{V_{2, t}}\right)\right) \\
V_{2, t+1}=V_{2, t}+\frac{1}{a_{2}}\left(R_{1, t}-R_{2, t}+V_{y, t}\right)+p_{t}-E_{t} \\
D_{2, t+1}=D_{2, t}+\frac{1}{a_{2}}\left(\frac{R_{1, t} D_{1, t}}{V_{1, t}}-\frac{R_{2, t} D_{2, t}}{V_{2, t}}\right)
\end{array}
$$

where $R_{2}$ is the mass of manure removed to be applied to land and $V_{y, t}$ is the mass of runoff from roofs and unroofed yards $\left(\mathrm{kg} \mathrm{d}^{-1}\right)$. The roof/yard runoff is calculated as follows: when $p_{t}>E_{t}$

$$
V_{y . t}=a_{y}\left(p_{t}-E_{t}\right)
$$

and otherwise $V_{y, t}=0 . a_{y}$ is the area of roofing + unroofed yard that discharges runoff to the slurry store $\left(\mathrm{m}^{2}\right)$. 